\title{
Photoredox Reactions of Lead(IV) and -(II) Hydroxo Complexes
}

\author{
Alexander Becht and Arnd Vogler* \\ Institut für Anorganische Chemie, Universität Regensburg, Universitätsstrasse 31, \\ W-8400 Regensburg, Germany
}

Received January 4, 1993

\begin{abstract}
Ligand-to-metal charge-transfer excitation of $\mathrm{Pb}(\mathrm{OH})_{6}{ }^{2-}$ in $0.1 \mathrm{M} \mathrm{NaOH}$ leads to the formation of $\mathrm{Pb}(\mathrm{OH})_{3}{ }^{-}$with $\phi=0.07$ at $\lambda_{\text {irr }}=254 \mathrm{~nm}$. Hydrogen peroxide was detected as an oxidation product. Upon sp excitation, $\mathrm{Pb}(\mathrm{OH})_{3}-$ in $0.1 \mathrm{M} \mathrm{NaOH}$ shows a yellow emission at $\lambda_{\max }=570 \mathrm{~nm}$ with $\phi=1.5 \times 10^{-3}$ at $\lambda_{\text {irr }}=254 \mathrm{~nm}$. In the presence of oxygen, this emission is partially quenched $\left(\phi=1.2 \times 10^{-3}\right)$ and $\mathrm{Pb}(\mathrm{OH})_{3}{ }^{-}$is photooxidized to $\mathrm{Pb}(\mathrm{OH})_{6}{ }^{2-}$ with $\phi=0.02$. A pseudo-photostationary state with $80 \% \mathrm{~Pb}(\mathrm{OH})_{6}{ }^{2-}$ is established. In the absence of oxygen, $\mathrm{Pb}(\mathrm{OH})_{3}{ }^{-}$ undergoes a photoreduction with the deposition of elemental lead.
\end{abstract}

\section{Introduction}

Intramolecular photoredox reactions of metal complexes can lead to oxidations of a variety of ligands. ${ }^{1-4}$ Generally, these ligand oxidations are induced by ligand-to-metal charge-transfer (LMCT) excited states. It is remarkable that, despite the importance of photochemical water oxidation, very little is known about such photoredox processes involving water or hydroxide as ligands. ${ }^{1-4}$ This lack of knowledge is certainly related to the high energy which is required to populate the corresponding LMCT states. ${ }^{5,6}$ They may not be accessible at all, or their population interferes with the presence of other excited states. The oxidation of water or hydroxide to stable products such as $\mathrm{O}_{2}$ or $\mathrm{H}_{2} \mathrm{O}_{2}$ requires multielectron-transfer processes. Since most metal complexes are not able to participate in photochemical multielectron-transfer reactions, there is much current interest to identify such systems. ${ }^{7,8}$

According to these considerations, homoleptic hydroxo complexes of main group metals with an $s^{0}$ electron configuration should be good candidates to observe a photochemical oxidation of two hydroxide ligands at one metal since $\mathrm{s}^{0}$ metals are generally reduced to $\mathrm{s}^{2}$ complexes as stable products. 9,10 We explored this possibility and selected the complex $\mathrm{Pb}(\mathrm{OH})_{6}{ }^{2-}$ for the present study. This choice was based on our experience with halide complexes of $\mathrm{s}^{0}$ metals which photochemically release halogens upon LMCT excitation. 9,10

A further attractive feature of main group metal compounds is the facile interconversion of $s^{0}$ and $s^{2}$ complexes. As it will be seen, such an interconversion can be achieved photochemically. Applications in photocatalysis are certainly feasible. However, the results of this study are not only of importance with regard to potential applications but are also interesting in their own right since observations on the photochemistry and photophysics of main group metal hydroxo complexes are here reported for the first time.

(1) Balzani, V.; Carassiti, V. Photochemistry of Coordination Compounds; Academic Press: New York, 1970.

(2) Concepts of Inorganic Photochemistry; Adamson, A. W., Fleischauer, P. D., Eds.; Wiley-Interscience: New York, 1975

(3) Ferraudi, G. J. Elements of Inorganic Photochemistry; Wiley-Interscience: New York, 1988.

(4) Sykora, J.; Sima, J. Coord. Chem. Rev. 1990, 107, 1.

(5) The one-electron oxidation of $\mathrm{OH}^{-}$requires $E^{\circ}=2.8 \mathrm{~V}$ : Endicott, J. F. In ref 2, p 88.

(6) Aqueous OH- shows a CTTS band at $\lambda_{\max }=187 \mathrm{~nm}$; Fox, M. In ref $2, \mathrm{p} 341$.

(7) For recent reviews see: (a) Balzani, V.; Scandola, F. Supramolecular Photochemistry; Horwood: Chichester, U.K., 1991. (b) Worl, L. A Strouse, G. F.; Younathan, J. N.; Baxter, S. M.; Meyer, T. J. J. Am Chem. Soc. $1990,112,7571$.

(8) Partigianoni, C. M.; Nocera, D. G. Inorg. Chem. 1990, 29, 2035.

(9) Vogler, A.; Paukner, A.; Kunkely, H. Coord. Chem. Rev. 1990, 57, 285

(10) Vogler, A.; Nikol, H. Pure Appl. Chem. 1992, 64, 1311.

\section{Experimental Section}

Materials. $\mathrm{Na}_{2}\left[\mathrm{~Pb}(\mathrm{OH})_{6}\right]$ was prepared according to a published procedure. ${ }^{11}$ Solutions of $\mathrm{Na}\left[\mathrm{Pb}(\mathrm{OH})_{3}\right]$ were obtained ${ }^{12,13}$ by dissolving $\mathrm{PbO}$ in aqueous $\mathrm{NaOH}$. The water used in the photochemical experiments was triply distilled.

Photolyses. The photolyses were carried out at room temperature in 1-cm spectrophotometer cells. The light source was a Hanovia $\mathrm{Xe} / \mathrm{Hg}$ $977 \mathrm{~B}-1(1000 \mathrm{~W})$ lamp. Monochromatic light $\left(\lambda_{\mathrm{irr}}=254 \mathrm{~nm}\right)$ was obtained by means of a Schoeffel GM 250-1 high-intensity monochromator. For quantum yield determinations, the complex concentrations were such as to have essentially complete light absorption. The total amount of photolysis was limited to less than $5 \%$ to avoid light absorption by the photoproduct. Absorbed light intensities were determined by a Polytec pyroelectric radiometer, which was calibrated and equipped with an RkP-345 detector.

Spectroscopy. Absorption spectra were recorded with a Uvikon 860 double-beam spectrophotometer. Emission spectra were obtained on a Hitachi 850 spectrofluorimeter which was equipped with a Hamamatsu 928 photomultiplier. The luminescence spectra were corrected for monochromator and photomultiplier efficiency. The relative emission intensities were recorded in power units. Absolute emission quantum yields were determined by comparison of integrated emission intensity of $\mathrm{Pb}(\mathrm{OH})_{3}{ }^{-}$with that of quinine sulfate in $0.5 \mathrm{M} \mathrm{H}_{2} \mathrm{SO}_{4}\left(\lambda_{\max }=452\right.$ $\mathrm{nm} ; \phi=0.546)^{14}$ under identical conditions such as exciting wavelength, optical density, and apparatus parameters.

Flash Photolysis. A flash photolysis apparatus of the conventional type was used. The main flash lamp dissipated $300 \mathrm{~J}$ at $17.2 \mathrm{kV}$ with a flash half-time of $10 \mu \mathrm{s}$. Transient absorption changes were recorded on a OS 250 oscilloscope (Gould Advanced). The argon-saturated solution was taken in a quartz cell with $10-\mathrm{cm}$ path length.

Analyses. Hydrogen peroxide was identified using the peroxide test of Merck (Merckoquant 10011). For the quantitative analysis of $\mathrm{H}_{2} \mathrm{O}_{2}$, the enzyme-catalyzed oxidation of scopoletin (7-hydroxy-6-methoxy$2 H$-1-benzopyran-2-one) and the subsequent decrease of fluorescence intensity was used..$^{15}$ The analysis was adjusted to our experimental conditions. After irradiation the solutions were neutralized with $1 \mathrm{M}$ $\mathrm{HCl}$, and the precipitated $\mathrm{PbO}_{2}$ was removed by centrifugation.

\section{Results}

Salts of $\mathrm{Pb}(\mathrm{OH})_{6}{ }^{2-11}$ are stable in aqueous solution only in the presence of an excess of alkali metal hydroxide. The absorption spectrum of $\mathrm{Pb}(\mathrm{OH})_{6}{ }^{2-}$ (Figure 1) consists of a UV band. Its

(11) Scholder, R.; Schwarz, H. In Handbuch der Präparativen Anorganischen Chemie; Brauer, G., Ed.; Enke: Stuttgart, Germany, 1981; Vol. 3, p 1771 .

(12) Garrett, A. B.; Vellenga, S.; Fontana, C. M. J. Am. Chem. Soc. 1939, $61,367$.

(13) Carell, B.; Olin, A. Acta Chem. Scand. 1960, 14, 1999.

(14) Demas, J. N.; Crosby, G. A. J. Phys. Chem. 1971, 75, 991.

(15) (a) Andreae, W. A. Nature 1955, 175, 859. (b) Perschke, H.; Broda, E. Nature 1961, 190, 257. (c) Corbett, J. T. J. Biochem. Biophys. Meth. 1989, 18, 297.

(C) 1993 American Chemical Society 


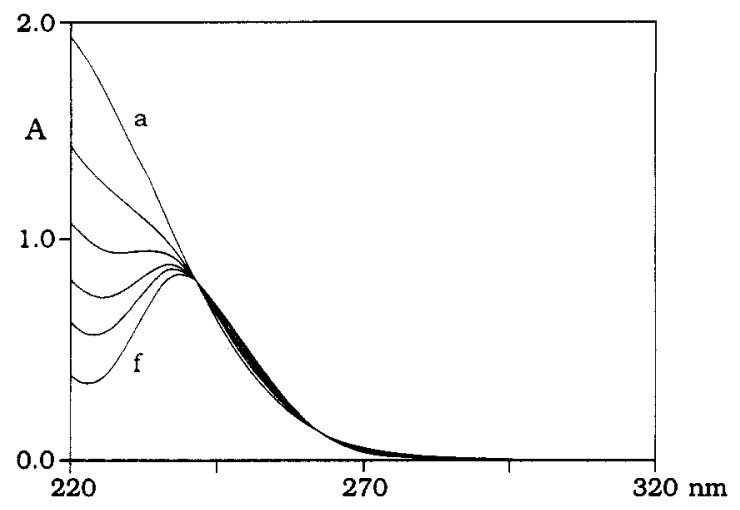

Figure 1. Spectral changes during the photolysis of $1.8 \times 10^{-4} \mathrm{M}$ $\mathrm{Na}_{2}\left[\mathrm{~Pb}(\mathrm{OH})_{6}\right]$ in $0.1 \mathrm{M} \mathrm{NaOH}$ at 0 (a), 2, 4, 6, 8, and $12 \mathrm{~min}$ (f) of irradiation time $\left(\lambda_{\mathrm{irr}}=254 \mathrm{~nm} ; 1-\mathrm{cm}\right.$ cell $)$.

maximum is assumed to appear below $220 \mathrm{~nm} . \mathrm{Pb}(\mathrm{OH})_{6}{ }^{2-}$ did not show any emission but was light sensitive. The photolysis ( $\lambda_{\text {irr }}=254 \mathrm{~nm}$ ) of argon-saturated solutions was assumed to lead to a reductive elimination according to the following equation:

$$
\mathrm{Pb}^{\mathrm{IV}}(\mathrm{OH})_{6}{ }^{2-} \stackrel{h \nu}{\rightarrow} \mathrm{Pb}^{\mathrm{II}}(\mathrm{OH})_{3}{ }^{-}+\mathrm{OH}^{-}+\mathrm{H}_{2} \mathrm{O}_{2}
$$

The spectral changes which accompanied the photolysis (Figure 1) include isosbestic points at 242 and $263 \mathrm{~nm}$. This clean photoreaction can be driven to completion. The final spectrum is that of $\mathrm{Pb}(\mathrm{OH})_{3}-$ (see below). Hydrogen peroxide was produced in less than stoichiometric amounts, depending on experimental conditions such as concentration, light intensity, and irradiation time. For example, irradiation of $7.2 \times 10^{-4} \mathrm{M} \mathrm{Na}_{2}\left[\mathrm{~Pb}(\mathrm{OH})_{6}\right]$ in $1 \mathrm{M}$ aqueous $\mathrm{NaOH}$ yielded $6.3 \times 10^{-5} \mathrm{M} \mathrm{Pb}(\mathrm{OH})_{3}-$ after 60 -s irradiation at $254 \mathrm{~nm}$ and a light intensity of $12.2 \mathrm{~mW} \cdot \mathrm{cm}^{-2}$. On the basis of the assumed stoichiometry, only $40 \%$ of the expected amount of $\mathrm{H}_{2} \mathrm{O}_{2}$ was recovered. When this irradiation was performed for $120 \mathrm{~s}$, the concentration of $\mathrm{Pb}(\mathrm{OH})_{3}{ }^{-}$was $1.2 \times$ $10^{-4} \mathrm{M}$ while the relative yield of $\mathrm{H}_{2} \mathrm{O}_{2}$ dropped to $24 \%$. It is assumed that $\mathrm{H}_{2} \mathrm{O}_{2}$ underwent a disproportionation to $\mathrm{H}_{2} \mathrm{O}$ and $\mathrm{O}_{2}$ by a secondary photolysis or by other side reactions. The quantum yield for the formation of $\mathrm{Pb}(\mathrm{OH})_{3}-$ was $\phi=0.07 \pm$ 0.01 at $\lambda_{\mathrm{ir}}=254 \mathrm{~nm}$. In the presence of oxygen, the photolysis of $\mathrm{Pb}(\mathrm{OH})_{6}{ }^{2-}$ was much slower and a complete conversion to $\mathrm{Pb}$ (II) was not achieved since $\mathrm{Pb}(\mathrm{OH})_{3}{ }^{-}$underwent a photooxidation back to $\mathrm{Pb}(\mathrm{OH})_{6}{ }^{2-}$.

A low-temperature $(77 \mathrm{~K})$ photolysis of $\mathrm{Pb}(\mathrm{OH})_{6}{ }^{2-}$ in $10 \mathrm{M}$ $\mathrm{NaOH}$ glasses was carried out in order to identify radicals by ESR spectroscopy. While $\mathrm{Pb}$ (III) ${ }^{16}$ was not detected, a weak signal with $g=2.0049$ is compatible with the presence of $\mathrm{OH}$ radicals. ${ }^{17}$

The flash photolysis of $2.0 \times 10^{-3} \mathrm{M} \mathrm{Pb}(\mathrm{OH})_{6}{ }^{2-}$ in $1 \mathrm{M} \mathrm{NaOH}$ under argon generated an intermediate which shows an absorption at $360 \mathrm{~nm}$. It decayed according to a first-order rate law with a lifetime of $\tau=5 \mu \mathrm{s}$. Halide or pseudohalide may be used to scavenge $\mathrm{OH}$ radicals generated in the flash photolysis. However, this method cannot be used here since these scavengers are known to produce solvated electrons at the irradiating wavelength required for the photolysis of $\mathrm{Pb}(\mathrm{OH})_{6}{ }^{2-} .18$ Moreover, halide ions would be incorporated as ligands since $s^{0}$ complexes such as $\mathrm{Pb}(\mathrm{OH})_{6}{ }^{2-}$ are rather labile. ${ }^{10,19}$

(16) (a) Booth, R. J.; Starkie, H. C.; Symons, M. C. R. J. Phys. Chem. 1972 76, 141. (b) Booth, R. J.; Starkie, H. C.; Symons, M. C. R.; Eachus, R. S. J. Chem. Soc., Dalton Trans. 1973, 2233. (c) Aleksandrov, A. I.; Prokofev, A. I.; Raspertova, Z. I.; Bubnov, N. N.; Kraevskij, S. L. Solinov, V. F. Dokl. Phys. Chem. (Engl. Transl.) 1985, 284, 973 .

(17) (a) Dibdin, G. H. J. Chem. Soc., Faraday Trans. 1967, 63, 2098. (b) Brivati, J. A.; Symons, M. C. R.; Tinling, D. J. A.; Wardale, H. W.: Williams, D. O. J. Chem. Soc., Faraday Trans. 1967, 63, 2112. (c) Hill, M. J.; Wyard, S. J. J. Phys. B 1968, 1, 289.

(18) Fox, M. In ref 2, p 335

(19) Vogler, A.; Nikol, H. Comments Inorg. Chem. 1993, 14, 245.

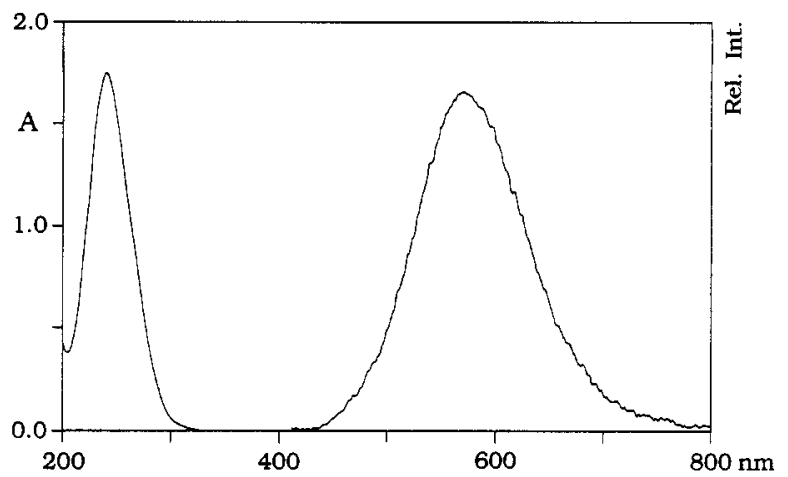

Figure 2. Electronic a bsorption (left side) and emission (right side) spectra of $3.9 \times 10^{-4} \mathrm{M} \mathrm{Na}\left[\mathrm{Pb}(\mathrm{OH})_{3}\right]$ in $0.1 \mathrm{M} \mathrm{NaOH}$ at room temperature $\left(1-\mathrm{cm}\right.$ cell; $\lambda_{\mathrm{exc}}=254 \mathrm{~nm}$; intensity in arbitrary units).

Solutions of $\mathrm{Pb}(\mathrm{OH})_{3}{ }^{-12,13}$ were obtained by dissolving $\mathrm{PbO}$ in aqueous alkali metal hydroxide. The absorption spectrum of $\mathrm{Pb}(\mathrm{OH})_{3}{ }^{-}$displays a single band (Figure 2) at $\lambda_{\max }=239 \mathrm{~nm}(\epsilon$ $\left.=4500 \mathrm{~L} \cdot \mathrm{mol}^{-1} \cdot \mathrm{cm}^{-1}\right)$. Argon-saturated solutions of $\mathrm{Pb}(\mathrm{OH})_{3}{ }^{-}$ in $0.1 \mathrm{M} \mathrm{NaOH}$ show a yellow emission at $\lambda_{\max }=570 \mathrm{~nm}$ (Figure 2) with $\phi=1.5 \times 10^{-3}$ at $\lambda_{\text {exc }}=254 \mathrm{~nm}$. The excitation spectrum agreed well with the absorption spectrum. In oxygen-saturated solutions, the emission quantum yield dropped to $\phi=1.2 \times 10^{-3}$.

In oxygen-saturated solutions $\left(\sim 10^{-3} \mathrm{MO}_{2}\right),{ }^{20}$ the irradiation of $\mathrm{Pb}(\mathrm{OH})_{3}{ }^{-}$in $0.1 \mathrm{M} \mathrm{NaOH}$ with $\lambda_{\text {irr }}=254 \mathrm{~nm}$ led to the formation of $\mathrm{Pb}(\mathrm{OH})_{6}{ }^{2-}$. The accompanying spectral changes were simply a reversal of those observed during the photolysis of $\mathrm{Pb}(\mathrm{OH})_{6}{ }^{2-}$ (Figure 1). Although isosbestic points at 242 and $263 \mathrm{~nm}$ indicate a clean photooxidation, a complete conversion could not be achieved since the photoproduct $\mathrm{Pb}(\mathrm{OH})_{6}{ }^{2-}$ is photoreduced back to $\mathrm{Pb}(\mathrm{OH})_{3}{ }^{-}$. A pseudo-photostationary state ${ }^{21}$ with $80 \% \mathrm{~Pb}(\mathrm{OH})_{6}{ }^{2-}$ was reached by bubbling a continuous stream of oxygen through the solution during the irradiation. At the beginning of the photolysis of $\mathrm{Pb}(\mathrm{OH})_{3}^{-}$, the formation of $\mathrm{Pb}(\mathrm{OH})_{6}{ }^{2-}$ proceeded with $\phi=0.020 \pm 0.002$ at $\lambda_{\text {irr }}=254 \mathrm{~nm}$.

In analogy to related photooxidations, 9,10 it was assumed that the stoichiometry corresponds to the equation

$$
\mathrm{Pb}^{\mathrm{II}}(\mathrm{OH})_{3}{ }^{-}+\mathrm{O}_{2}+2 \mathrm{H}_{2} \mathrm{O}+\mathrm{OH}^{-} \stackrel{h \nu}{\rightarrow} \mathrm{Pb}^{\mathrm{IV}}(\mathrm{OH})_{6}{ }^{2-}+\mathrm{H}_{2} \mathrm{O}_{2}
$$

However, only traces of $\mathrm{H}_{2} \mathrm{O}_{2}$ were detected.

In the absence of oxygen, $\mathrm{Pb}(\mathrm{OH})_{3}-$ in $1 \mathrm{M} \mathrm{NaOH}$ underwent a photoreduction to metallic lead. The irradiation of $\mathrm{Pb}(\mathrm{OH})_{3}-$ in argon-saturated solutions was accompanied by the formation of a black colloid which led to an apparent increase of the optical density over the entire UV/visible wavelength region. This increase was larger toward shorter wavelength, in accordance with the optical properties of metal colloids. ${ }^{22}$ The disappearance of $\mathrm{Pb}(\mathrm{OH})_{3}$ - was measured by the decrease of the extinction at $239 \mathrm{~nm}$ in the beginning of the photolysis before the metal deposition obscured the spectral measurements. At $\lambda_{\text {irr }}=254$ $\mathrm{nm}, \mathrm{Pb}(\mathrm{OH})_{3}$-disappeared with $\phi=0.013 \pm 0.003$. Since $\mathrm{H}_{2} \mathrm{O}_{2}$ as a possible oxidation product was not detected, it is assumed that the photolysis occurs with the overall stoichiometry

$$
2 \mathrm{~Pb}^{\mathrm{II}}(\mathrm{OH})_{3}{ }^{-} \stackrel{h \nu}{\rightarrow} 2 \mathrm{~Pb}^{0}+\mathrm{O}_{2}+2 \mathrm{H}_{2} \mathrm{O}+2 \mathrm{OH}^{-}
$$

However, this stoichiometry does not exclude the primary formation of $\mathrm{H}_{2} \mathrm{O}_{2}$, which may undergo a disproportionation to

(20) Bruhn, G.; Gerlach, J.; Pawlek, F. Z. Anorg. Allg. Chem. 1965, 337, 68.

(21) The photostationary state is termed "pseudo" since it refers only to the equilibrium between $\mathrm{Pb}(\mathrm{OH})_{6}{ }^{2-}$ and $\mathrm{Pb}(\mathrm{OH})_{3}{ }^{-}$while other reactants such as $\mathrm{O}_{2}$ or products (e.g. $\mathrm{H}_{2} \mathrm{O}_{2}$ ) are not included.

(22) Vogler, A.; Quett, C.; Kunkely, H. Ber. Bunsen-Ges. Phys. Chem. 1988, 92,1486 . 
water and oxygen. Metals are well-known to catalyze the decomposition of hydrogen peroxide. ${ }^{23}$

\section{Discussion}

The complex $\mathrm{Pb}(\mathrm{OH})_{6}{ }^{2-}$ contains $\mathrm{Pb}(\mathrm{IV})$ with an empty valence shell ( $s^{0}$ electron configuration). Accordingly, only electronic transitions of the LMCT type are possible. In analogy to related complexes such as $\mathrm{PbCl}_{6}^{2-}, \mathrm{SnCl}_{6}{ }^{2-}$, or $\mathrm{SbCl}_{6},-9,10$ the longest wavelength absorption of $\mathrm{Pb}(\mathrm{OH})_{6}{ }^{2-}$ is assigned to the $t_{1 \mathrm{u}} \rightarrow \mathrm{a}_{1 \mathrm{~g}}$ transition from filled orbitals of $\mathrm{OH}^{-}$to the empty antibonding s orbital of $\mathrm{Pb}(\mathrm{IV})$. Although $\mathrm{Pb}$ (IV) is a strong oxidant, this LMCT transition occurs at very high energies since $\mathrm{OH}^{-}$is only a very weak reductant. ${ }^{5,6}$

LMCT excitation of $\mathrm{Pb}(\mathrm{OH})_{6}{ }^{2-}$ leads to a reductive elimination with the formation of $\mathrm{Pb}(\mathrm{OH})_{3}-$ and $\mathrm{H}_{2} \mathrm{O}_{2}$, which was found in less than stoichiometric amounts. Since $\mathrm{H}_{2} \mathrm{O}_{2}$ absorbs in the same wavelength region as $\mathrm{Pb}(\mathrm{OH})_{6}{ }^{2-}$, it can disappear in a secondary photolysis. The decomposition of hydrogen peroxide is a well-known photoreaction. ${ }^{24}$ It is also feasible that other side reactions of the photolysis of $\mathrm{Pb}(\mathrm{OH})_{6}{ }^{2-}$ prevent the stoichiometric production of $\mathrm{H}_{2} \mathrm{O}_{2}$ (see below).

The photoreaction of $\mathrm{Pb}(\mathrm{OH})_{6}{ }^{2-}$ may proceed by the release of $\mathrm{H}_{2} \mathrm{O}_{2}$ in a concerted reaction without the intermediate formation of $\mathrm{Pb}$ (III) and/or $\mathrm{OH}$ radicals. As an alternative and in analogy to $\mathrm{PbCl}_{4},{ }^{25}$ the photoreduction of $\mathrm{Pb}(\mathrm{OH})_{6}{ }^{2-}$ could take place in two consecutive one-electron-transfer steps:

$$
\begin{gathered}
\mathrm{Pb}^{\mathrm{IV}}(\mathrm{OH})_{6}{ }^{2-} \stackrel{h v}{\rightarrow} \mathrm{Pb}^{\mathrm{III}}(\mathrm{OH})_{5}{ }^{2-}+{ }^{\circ} \mathrm{OH} \\
\text { and } \mathrm{Pb}^{\mathrm{III}}(\mathrm{OH})_{5}{ }^{2-} \rightarrow \mathrm{Pb}^{\mathrm{II}}(\mathrm{OH})_{4}{ }^{2-}+{ }^{\circ} \mathrm{OH} \\
\left(\text { or } 2 \mathrm{~Pb}^{\mathrm{III}}(\mathrm{OH})_{5}{ }^{2-} \rightarrow \mathrm{Pb}^{\mathrm{IV}}(\mathrm{OH})_{6}{ }^{2-}+\mathrm{Pb}^{\mathrm{II}}(\mathrm{OH})_{4}{ }^{2-}\right)
\end{gathered}
$$

Since $\mathrm{Pb}(\mathrm{OH})_{4}{ }^{2-}$ is apparently not stable, ${ }^{13,26} \mathrm{~Pb}(\mathrm{OH})_{3}{ }^{-}$is formed as final product. The hydroxyl radicals can dimerize to yield $\mathrm{H}_{2} \mathrm{O}_{2}$. However, owing to the reactivity of $\mathrm{OH}$ radicals, they can also attack other species. For example, hydroxyl radicals are known to react with $\mathrm{H}_{2} \mathrm{O}_{2}$ in a chain reaction which leads to the disproportionation of $\mathrm{H}_{2} \mathrm{O}_{2} .{ }^{24}$

The intermediate formation of $\mathrm{OH}$ radicals and $\mathrm{Pb}^{\mathrm{III}}$ was explored by low-temperature and flash photolysis. Upon irra-

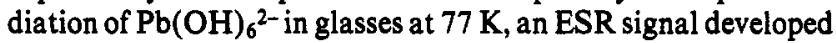
which is compatible with the presence of $\mathrm{OH}$ radicals. ${ }^{17}$ This signal was rather weak. However, the room-temperature flash photolysis yielded a distinct transient with an absorption at 360 $\mathrm{nm}$ which is assumed to be $\mathrm{Pb}$ III $(\mathrm{OH})_{5}{ }^{2-}$ or $\mathrm{Pb}$ decays with $k=2 \times 10^{5} \mathrm{~s}^{-1}$ according to first-order kinetics. It is suggested that this decay involves the release of a second $\mathrm{OH}$

(23) Weiss, J. J. Chem. Soc., Faraday Trans. 1935, 31, 1547.

(24) (a) Hunt, J. P.; Taube, H. J. Am. Chem. Soc. 1952, 74, 5999. (b) Dainton, F. S.; Rowbottom, J. J. Chem. Soc., Faraday Trans. 1953, 49, 1160. (c) Anbar, M. J. Chem. Soc., Faraday Trans. 1961, 57,971. (d) Lunak, S.; Sedlak, P. J. Photochem. Photobiol. A: Chem. 1992, 68, 1. (25) Blazejowski, J.; Szychlinski, J. J. Photochem. 1979, 10, 45.

(26) $\mathrm{PbCl}_{3}$ - can add a further $\mathrm{Cl}^{-}$to yield $\mathrm{PbCl}_{4}{ }^{2-}$.27 Since the spectrum of $\mathrm{Pb}(\mathrm{OH})_{3}{ }^{-}$does not change upon increasing $\mathrm{OH}^{-}$concentration, it is concluded that $\mathrm{Pb}(\mathrm{OH})_{4}^{2-}$ does not exist under these conditions.

(27) Nikol, H.; Becht, A.; Vogler, A. Inorg. Chem. 1992, 31, 3277.

(28) Mosseri, S.; Henglein, A.; Janata, E. J. Phys. Chem. 1990, 94, 2722. radical. Unfortunately, for the photolysis of $\mathrm{Pb}(\mathrm{OH})_{6}{ }^{2-}, \mathrm{OH}$ radicals cannot be detected by scavenging techniques. Light absorption and photochemistry of suitable traps such as aromatic or olefinic compounds would interfere with the photochemistry of $\mathrm{Pb}(\mathrm{OH})_{6}{ }^{2-}$.

Although $\mathrm{Pb}(\mathrm{OH})_{3}$ - is a well-known species, ${ }^{12,13,29}$ its structure has not yet been determined. However, there is little doubt that it has a trigonal pyramidal geometry $\left(C_{3 v}\right)$. This structure is generally found for simple three-coordinate $s^{2}$ compounds. ${ }^{19}$ In analogy to other $\mathrm{s}^{2}$ complexes, $9,10,19$ including $\mathrm{PbCl}_{3}{ }^{-27}$ the longestwavelength absorption of $\mathrm{Pb}(\mathrm{OH})_{3}{ }^{-}$at $\lambda_{\max }=239 \mathrm{~nm}$ is certainly the $A$ band, which is assigned to the metal-centered sp transition ${ }^{1} S_{0} \rightarrow{ }^{3} P_{1}$. The higher-energy sp transitions ( $B$ and $C$ bands) do not occur above $220 \mathrm{~nm}$.

Although many halide complexes of $\mathrm{s}^{2}$ ions have been shown to emit, $9,10,19$ the photoluminescence of $\mathrm{Pb}(\mathrm{OH})_{3}$-is a remarkable observation. It represents the first example of an emitting hydroxo complex of $\mathrm{s}^{2}$ metals. The emission of $\mathrm{Pb}(\mathrm{OH})_{3}-$ at $\lambda_{\max }=570$ $\mathrm{nm}$ is assigned to the ${ }^{3} \mathrm{P}_{1} \rightarrow{ }^{1} \mathrm{~S}_{0}$ transition. The large Stokes shift $\Delta E=24300 \mathrm{~cm}^{-1}$ indicates a considerable structural rearrangement in the excited state. Others $\mathrm{s}^{2}$ complexes of the $\mathrm{ML}_{3}$ type are also characterized by such large Stokes shifts. ${ }^{19,27}$ It is assumed that the trigonal pyramidal structure of $\mathrm{Pb}(\mathrm{OH})_{3}-$ rearranges toward a trigonal planar geometry in the sp excited state.

The luminescence quenching by oxygen is associated with the photooxidation of $\mathrm{Pb}(\mathrm{OH})_{3}{ }^{-}$to $\mathrm{Pb}(\mathrm{OH})_{6}{ }^{2-}$. Similar photooxidations of other $\mathrm{s}^{2}$ ions such as $\mathrm{Tl}^{+}$and $\mathrm{Sb}^{3+}$ have been shown to be accompanied by the production of $\mathrm{H}_{2} \mathrm{O}_{2} \cdot 9,10$ However, in the case of $\mathrm{Pb}(\mathrm{OH})_{3}{ }^{-}$, only traces of $\mathrm{H}_{2} \mathrm{O}_{2}$ were detected. Since $\mathrm{Pb}(\mathrm{OH})_{3}{ }^{-}$and $\mathrm{H}_{2} \mathrm{O}_{2}$ absorb at similar energies, a secondary photolysis of hydrogen peroxide can take place. The photodecomposition of hydrogen peroxide is facilitated by a chain reaction ${ }^{24}$ (see above).

During the photolysis of $\mathrm{Pb}(\mathrm{OH})_{3}{ }^{-}$, the product $\mathrm{Pb}(\mathrm{OH})_{6}{ }^{2-}$ is accumulating. It starts to absorb light and is photoreduced back to $\mathrm{Pb}(\mathrm{OH})_{3}{ }^{-}$. If an excess of oxygen is admitted, a pseudophotostationary state with about $20 \% \mathrm{~Pb}(\mathrm{OH})_{3}$ - is established. This equilibrium can also be calculated using a simple equation which requires the knowledge of the extinction coefficients at the irradiation wavelength and the quantum yields of both photoreactions. ${ }^{30}$ The calculated value agrees rather well with the experimental result.

In the absence of oxygen, the photolysis of $\mathrm{Pb}(\mathrm{OH})_{3}{ }^{-}$leads to the formation of elemental lead. Since $\mathrm{H}_{2} \mathrm{O}_{2}$ was not detected, molecular oxygen can be the only oxidation product of this photolysis. Although the investigation of this photoreaction was not within the scope of the present work, a tentative explanation for these observations is given. The sp excited state of $\mathrm{Pb}(\mathrm{OH})_{3}{ }^{-}$ is certainly not only strongly reducing but also oxidizing. The photolysis thus can be induced by an initial intra- and intermolecular electron transfer from hydroxide to $\mathrm{Pb}^{2+}$. Secondary reactions such as a disproportionation of $\mathrm{Pb}^{+}$to $\mathrm{Pb}^{0}$ and $\mathrm{Pb}^{2+}$ may finally lead to the deposition of lead.

Acknowledgment. Support of this research by the BMFT (Grant 0329075A) is gratefully acknowledged. We thank Dr. Horst Kunkely for the flash photolysis experiments and Andrea Wettstein for the ESR measurements.

(29) Birss, V. I.; Shevalier, M. T. J. Electrochem. Soc. 1987, 134, 802.

(30) Adamson, A. W. In ref 2 , p 415. 